\title{
SPRINGS (CLASSIFICATION, FUNCTION, CAPTURING)
}

\author{
Soulios G. ${ }^{1}$ \\ ${ }^{1}$ Department of Geology, Aristotle University of Thessaloniki,gsoulios@geo.auth.gr
}

\begin{abstract}
Todd, K (1980) proposed the following definition for springs: "a concentrated discharge of groundwater that emerges on the ground as a stream of water that flows freely". Spring is distinguished from water leak that is a normally diffused but extended (linear or 2D) slower movement of groundwater towards the ground surface. Uprush is every groundwater emergence on the ground surface or through the bed of water bodies (river, lake, sea).

In the context of hydrogeology springs and uprushes in general are in fact "overflows" of aquifers; hence they serve as aquifer discharge mechanisms. Springs emerge at the cross section of groundwater level with the topographic relief.

Springs are a strong evidence of rich groundwater potential. A big number of small springs emerging at the margins of basins or the hill slopes are an evidence of a shallow aquifer of low hydraulic conductivity. On the contrary, big springs emerging at the bottom of valleys, i.e. the basic geomorphological level, are an indication of a high potential aquifer characterized by considerable values of hydraulic conductivity.
\end{abstract}

\section{Spring classification criteria}

Spring classification in categories and types may be performed on the basis of various alternative criteria (several types may be distinguished in each category). Different spring categories occur depending on the criterion selected for classification. Hence, the following criteria may be used for spring classification:

- Mean spring discharge q (may be classified in very low, low, average, large, very large springs).

- Annual fluctuation of spring discharge, i.e. on the basis of the ratio $\omega=\frac{\mathrm{q}_{\mathrm{M}}}{\mathrm{q}_{\mathrm{m}}}$, where $\mathrm{q}_{\mathrm{M}}$ and $\mathrm{q}_{\mathrm{m}}$ are the maximum and minimum annual spring discharge, respectively $(\omega<5$ constant discharge spring, $\omega>5$ variable discharge spring).

- Discharge regime (perennial, seasonal, intermittent springs).

- Lithology of the recharge basin (karstic, ophiolitic, etc).

- Spring water chemistry and concentration of various ions (bicarbonate, alkaline, magnesium, etc).

- Water temperature (cold, normal, warm springs).

- Location of emergence relative to the seashore (inland, coastal, sub-marine springs).

\section{Spring categories with regards to the geological structure}

i Contact springs, figure 1 . They are formed on the contact of a permeable formation (e.g. lime- 


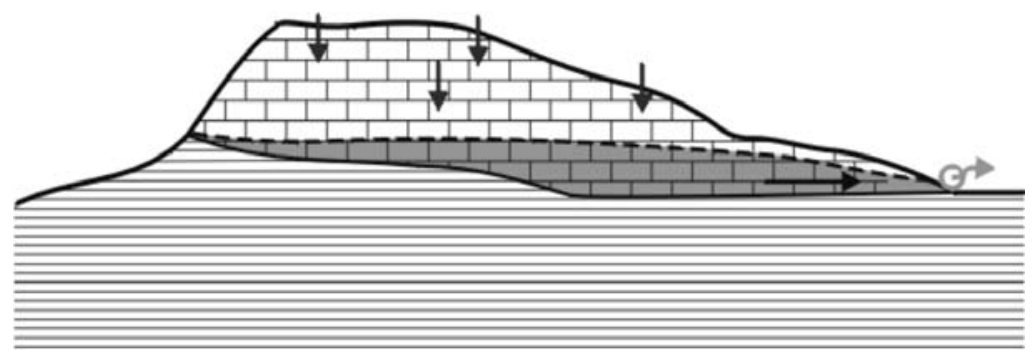

Fig. 1: Contact spring.

stone) that is superimposed on an impermeable formation, such as argillaceous schist. Those springs are related to perched aquifers.

Those springs emerge above the base level and are usually low to average. Their recharge basin is small and discharged volumes are not considerable. Their character is often seasonal and their discharge variable $(\omega>5)$.

ii Quasy-contact springs, figure 2. A geological formation is often not characterized by uniform values of hydraulic conductivities throughout its entire vertical extent, either due to minor lithological variations, or mainly due to the development of zones of higher density in cracks and fissures. As a result, zones of higher hydraulic conductivity may exist upon zones of lower hydraulic conductivity. As illustrated in figure 2, in these cases seasonal or permanent perched aquifers of low potential may exist that are discharged at a spring.

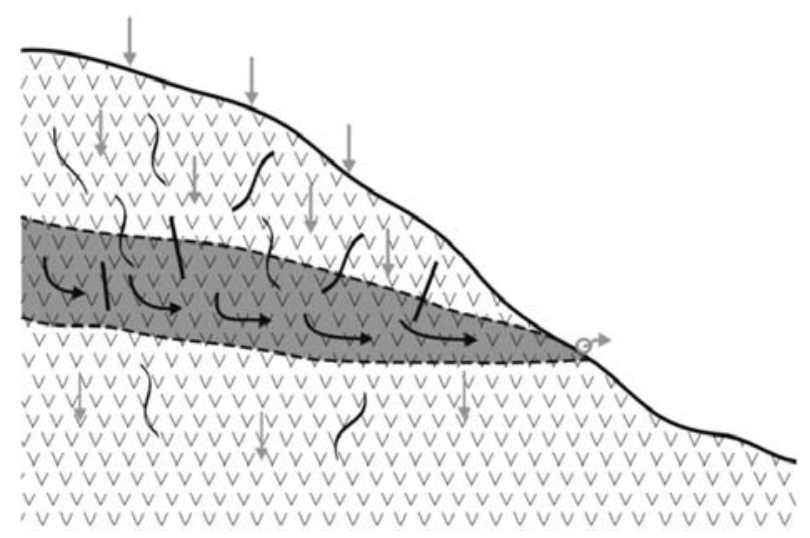

Fig. 2: Quasi-contact spring.

Quasi-contact springs are often seasonal with highly variable low discharge. Discharged volumes are low. Springs of this type emerge above base level.

iii Fault springs, figure 3. Creation of this type of spring is related to a fault that shifts to contact a permeable formation, i.e. an aquifer with an impermeable formation. Hence, the aquifer overflows at the fault. Those springs may be regarded as overflow springs (see below). Springs of this category often emerge close to the base level, may be of either low or high discharge rates whilst their discharge is variable. Recharge basins of those springs are often large and consequently total discharge volumes are high. 


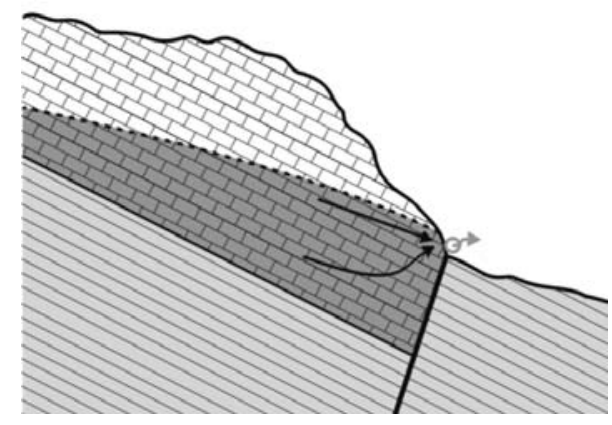

Fig. 3: Fault spring.

iv Overflow springs, figure 4. Several terms exist in the Greek reference literature for this particular category of springs and probably the presented one describes best their characteristics.

Normally those springs emerge at the regional base level. They are perennial, with a constant or at least not highly variable discharge rate and are related to high potential aquifers, which consequently results in large total discharge volumes.

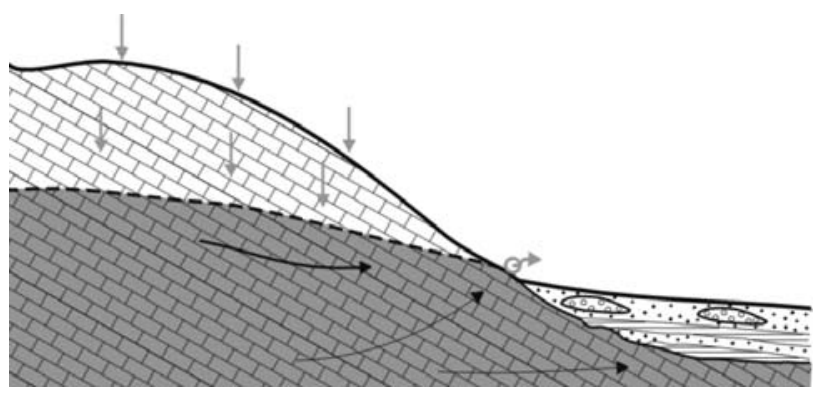

Fig. 4: Overflow spring.

In practice there are numerous combinations of afore presented spring categories which in fact mean that each spring may be considered to form a unique category on its own. Here are some special spring types that may be classified in one of the previously discussed categories.

- Irregular spring, figure 5. Water reaches the emergence point trough a siphon. In order for the spring to discharge water, groundwater level should reach the highest level of the siphon (AA'). If groundwater level falls below level BB' no water will be discharged from the spring, even if BB' level is above the elevation of the emergence point. As a result, the spring cease to discharge suddenly as it starts to discharge again given the right conditions. Hence spring operates at irregular intervals.

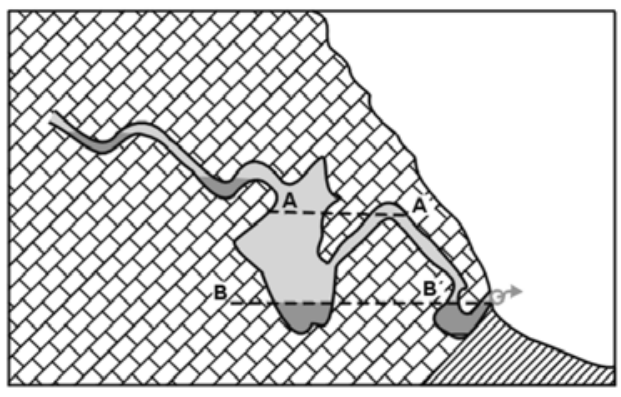

Fig. 5: Irregular spring. 
- Vauclusian spring, figure 6. This term originates from the famous spring of Vaucluse, at the region of Avignon (France), which is a large spring with a mean annual discharge in the order of $30-40 \mathrm{~m}^{3} / \mathrm{sec}$. This spring is characterized by the existence of a large and deep conduit through which water emerges at ground surface. Water moves upwards due to hydrostatic pressure since the surrounding rock is solid and impermeable.

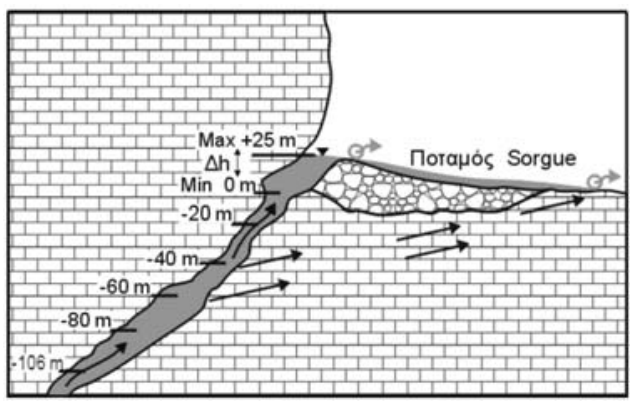

Fig. 6: Vauclusian spring.

- Uplift fault spring, figure 7. Emergence of this spring at the particular point is attributed to a fault that has uplifted an aquifer near ground surface. Hydrostatic pressure forces water to flow upwards through the permeable zone that is created due to fault tectonics and emerge at the fault line on ground surface. At the point of emergence the uplift movement of the water may be seen.

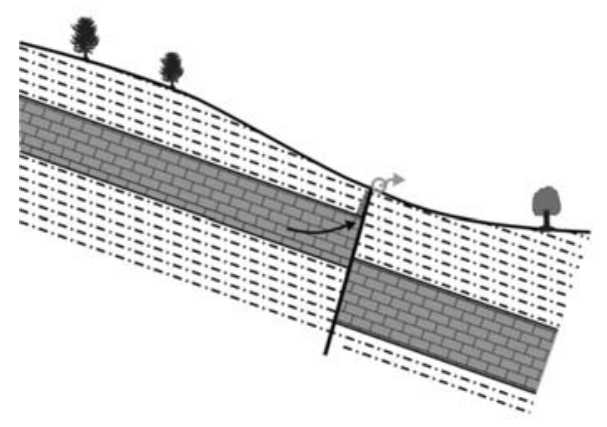

Fig. 7: Uplift fault spring.

- Trop-plein spring. Occasionally, an aquifer that is being discharged to a spring may receive excessive recharge due to heavy rainfalls and groundwater levels may rise considerably. In such cases, it is possible that groundwater levels intersect the topography and a second spring is thus formed, which operates in parallel to the main spring, as illustrated in figure 8 . This second spring is seasonal and operates only during periods of highly elevated groundwater levels.

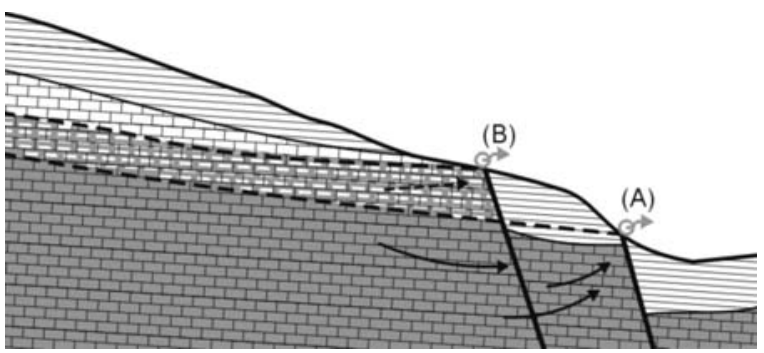

Fig. 8: Uplift fault (A) and Trop-plein (B) spring. 
(a)

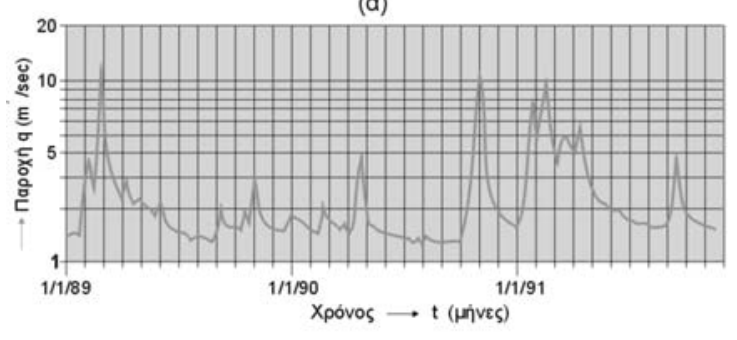

(B)
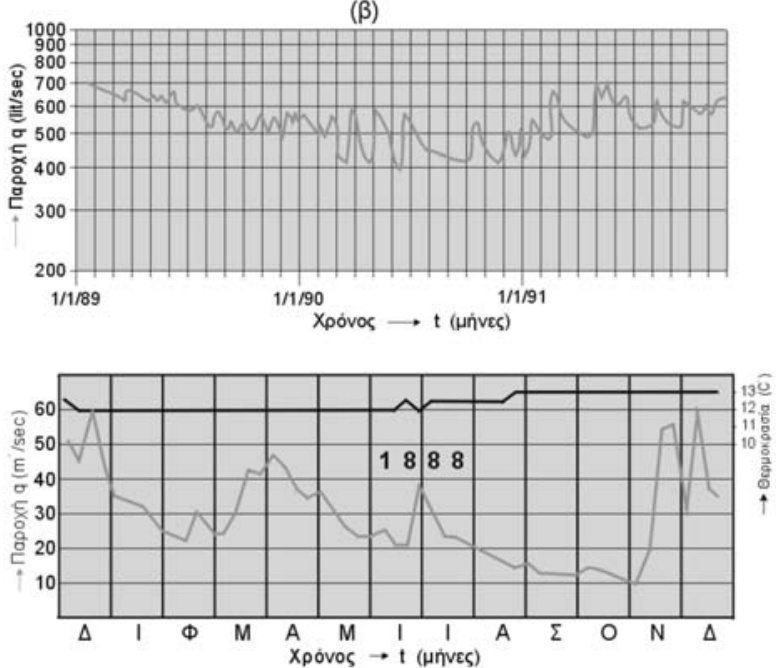

Fig. 9: Spring hydrographs (a) Aghios Nikolaos of Naoussa spring, (b) Aghios Ioannis of Serres spring, (c) Vaucluse (Avignon-France) spring.

Other special types of springs include thermal and coastal and sub-marine springs that will however be discussed on following chapters.

\section{Spring function - Hydrographs -Recharge Zone}

i It is obvious that every spring is related to an aquifer the groundwater level of which controls its discharge rate: High level corresponds to high discharge and low level corresponds to low discharge. When groundwater level declines below the emergence point the spring ceases to discharge.

ii Figure 9 illustrates the hydrographs of three springs:

(a) Aghios Nikolaos of Naoussa spring, characterized by high discharge variability $(\omega>10)$,

(b) Aghios Ioannis of Serres spring characterized by low discharge variability $(\omega<5)$,

(c) Vaucluse (Avignon-France) spring, for year 1888, also characterized by high discharge variability $(\omega>5)$.

iii Each spring has a corresponding recharge zone, i.e. an area the groundwater of which drains to the spring. The larger the recharge area is the higher the discharge of the spring is. Precipitation depth and infiltration coefficient are also two factors that control the discharge. 


\section{Spring recession equations}

Springs may be considered as a system comprising an "input", (which corresponds to infiltration within the recharge zone, or any other form of recharge), an aquifer (or an aquifer system) which transforms rain to discharge and therefore acts as "transformation function" and an "output" which is the spring discharge, i.e. the system is "Hyetograph - Transformation function - Hydrograph".

At this system, the "rising curve" of the hydrograph that represents the increase of the spring discharge, depends on the characteristics of the aquifer and the rainfall (entrance), while the "recession curve" depends only on the characteristics of the aquifer. Therefore, most of the suggested equations refer to recession curve.

i. Maillet's formula (1905). This formula depends on a conceptual model, according to which, the discharge of an aquifer is accomplished through an opening, like the discharge that takes place in pot through a porous cap. Therefore, the aquifer is simulated as a pot. Based on this correspondence, Maillet concluded to the exponential equation that expresses the exponential reduction of the discharge.

$$
\mathrm{q}=\text { qoe-at }
$$

where, $\mathrm{q}_{\mathrm{o}}=$ is the initial discharge of the spring at starting time $\mathrm{t}_{\mathrm{o}}$,

$\mathrm{t}=$ is the time duration, in days, since the time $\mathrm{t}_{\mathrm{o}}$,

$\mathrm{q}=$ is the water discharge of the spring at some time $\mathrm{t}$,

$\mathrm{e}=$ is the base of the napierian logarithm $(=2.71)$,

$\mathrm{a}=\mathrm{is}$ a coefficient, known as recession coefficient or coefficient of tarissement, with dimension $\mathrm{T}^{-1}$ and time unit per day.

The recession coefficient is characteristic for each spring. This coefficient depends on the following parameters:

- The aquifer permeability $\mathrm{k}$ : the higher the $\mathrm{k}$, the higher the coefficient a.

- The storage coefficient $\mathrm{S}$ ( or the effective porosity $\mathrm{m}_{\mathrm{e}}$ ): the higher the $\mathrm{S}$, the lower the coefficient $\mathrm{a}$.

- The size of the aquifer: the bigger the size, the lower the value of coefficient a.

- The shape and the transmissivity coefficient $(\mathrm{T})$ of the aquifer, the presence of relatively impermeable intermediate zones or layers, etc.

The recession coefficient has a physical meaning, since it corresponds to the physical properties of the system "aquifer-spring". Practically, this coefficient represents the daily spring discharge recession rate, during the recession period of the hydrograph.

An application of Maillet's equation at Korisos (Kastoria) spring is shown in Fig. 10. It is observed that the discharge values at the beginning of the depletion curve deviate from the straight line (which corresponds to the recession curve).

It is possible to calculate the effective reserves of a spring at a specific time point " $t$ " during the dry period, if the recession coefficient " $a$ " and the discharge of the spring " $q$ " at the specific time point " $t$ " are known. In fact, if we integrate over time " $t$ " the second part of equation (1), we can calculate them as follows:

$$
W=\int_{t=0}^{\infty} q \cdot e^{-a t} d t
$$

or

$$
\mathrm{W}=\frac{\mathrm{c} . \mathrm{q}}{\mathrm{a}} \quad \text { (3) hence } \mathrm{W}=\frac{84.660 \mathrm{q}}{\mathrm{a}}
$$



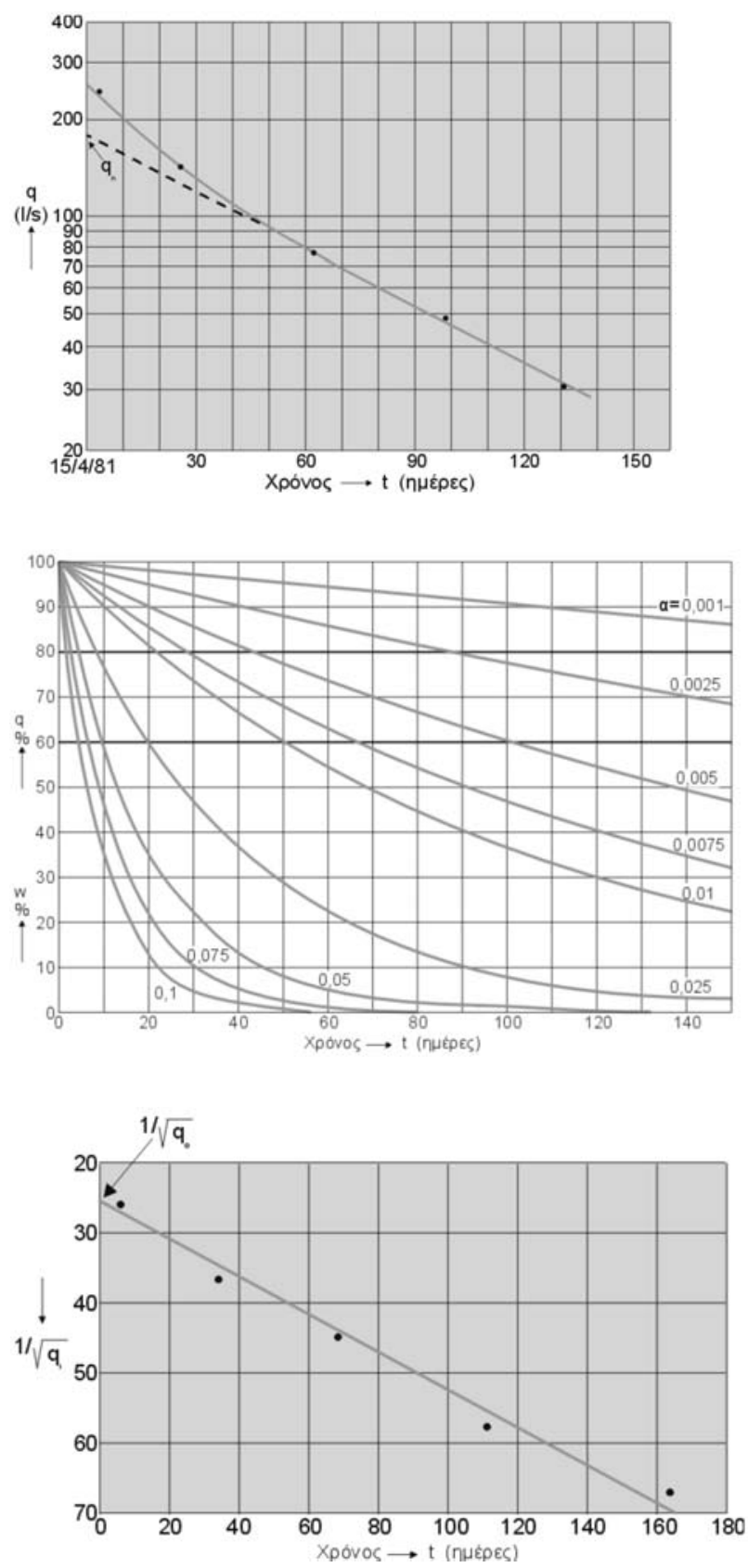

Fig. 10: Application of Maillet's equation in Korisos (Kastoria) spring.

Fig. 11: Reduction of the discharge (q) and of the reserves (W) of a spring over time (t) during the dry period, in relation to the recession coefficient a.

Fig. 12: Application of Tison's formula at the Korisos (Kastoria) spring.

Where $\mathrm{c}=$ integration constant; $\mathrm{c}=86.400$, the seconds of a 24-hour day, since " $\mathrm{q}$ " is calculated as volume/sec and a is calculated per day.

The graphs of Fig. 11 show the comparative (percentage) reduction of the discharge rate " $q$ ", and the evacuable reserves as a function of the time $t$ (since the beginning of the dry period) and the recession coefficient a. 
ii. Tison formula (1960). This formula is also based on a conceptual model. According to Tison, the aquifer discharge is not point but linear, which means that the aquifer is discharged along one side of the aquifer, through several spouts along a line. Therefore, Tison proposed the "hyperbolic formula":

$$
q=\frac{q_{0}}{(1+a t)^{2}}
$$

The coefficient "a" in this formula is different from Maillet's formula "a".

Tison's formula (1960) was not widely applied or referenced in the international literature. Figure 12 shows an application of Tison's formula at the Korisos spring (Kastoria), where it was calculated that $\mathrm{a}=1,09 \times 10^{-2} \mathrm{~d}^{-1}$ and $\mathrm{q}_{0}=0,16$.

The evacuable reserves according to Tison (1960) are calculated from the equation

$$
\mathrm{W}=\frac{86.400 \mathrm{q}_{0}}{\mathrm{a}(1+\mathrm{at})}
$$

iii. Forkasiewicz-Paloc formula (1967). It is a formula based on an empirical approach. These two researchers observed that Maillet's recession coefficient was not always constant for a spring and that Maillet's formula is valid only for the dry period, for the recession segment of the hydrograph and not for the rising segment. So, they concluded to the formula:

$$
\frac{1}{q^{2}}=\frac{1}{q_{0}^{2}}+\beta \mathrm{t}
$$

where $\beta=$ discharge recession coefficient, which has no physical meaning nor it corresponds to a property or parameter of "aquifers-spring" system.

This formula was not widely applied or referenced in the international literature. Fig. 13 illustrates an application of this formula, implemented by the above researchers, for a spring in France.

Finally, it is mentioned that the integration of this formula does not provide the volume of the evacuable reserves at a specific time point, but it provides the volume $\mathrm{W}$ that will flow out of the spring between time $\mathrm{t}_{1}\left(\mathrm{q}_{1}\right)$ and $\mathrm{t}_{2}\left(\mathrm{q}_{2}\right)$ :

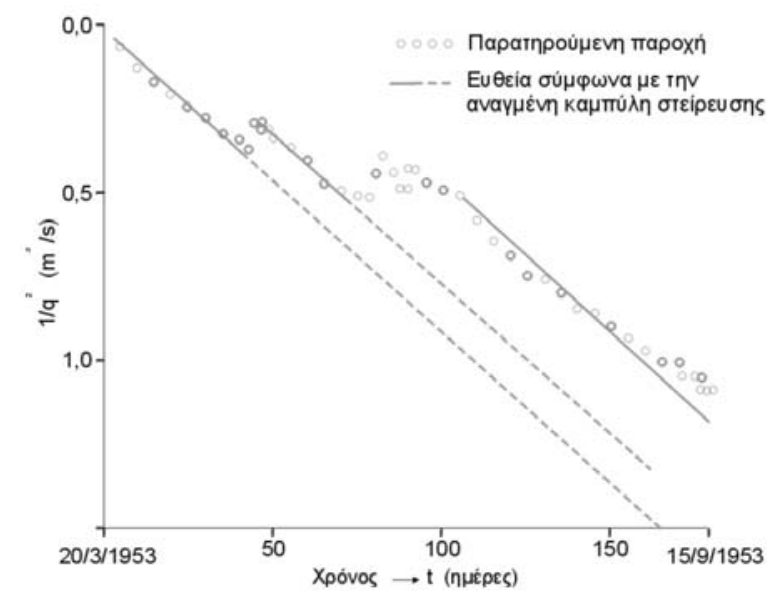

Fig. 13: Application of ForkasiewiczPaloc equation at the spring of Lez (Montpellier, France). 


$$
\mathrm{W}=\frac{2}{\beta}\left(\frac{1}{\mathrm{q}_{2}}-\frac{1}{\mathrm{q}_{1}}\right) 86.400
$$

iv. Schoeller formula (1967). It is a new approach of the Maillet's formula. Theoretically, it concerns karstic springs, but it may be also applicable in other types of springs. It assumes that inside the karstic mass exist:

- A conduit network of big potholes, fissures etc, through which the circulation of the groundwater towards the spring is rapid.

- A conduit network of medium size fissures and other types of discontinuities, through which the groundwater flows with relatively lower velocity.

- A conduit network of small and fine joints, through which groundwater flows with small velocity.

Therefore, the hydrograph is decomposed into several components (straight lines) from which usually only 2 or 3 contribute significantly to the total discharge of the spring. The formula that describes the hydrograph decomposition is:

$$
\mathrm{q}=q_{01} e^{-a_{1} t}+q_{02} e^{-a_{2} t}+q_{03} e^{-a_{3} t}
$$

Fig. 14 illustrates the application of the above formulas for the springs of Voula, Trikala.

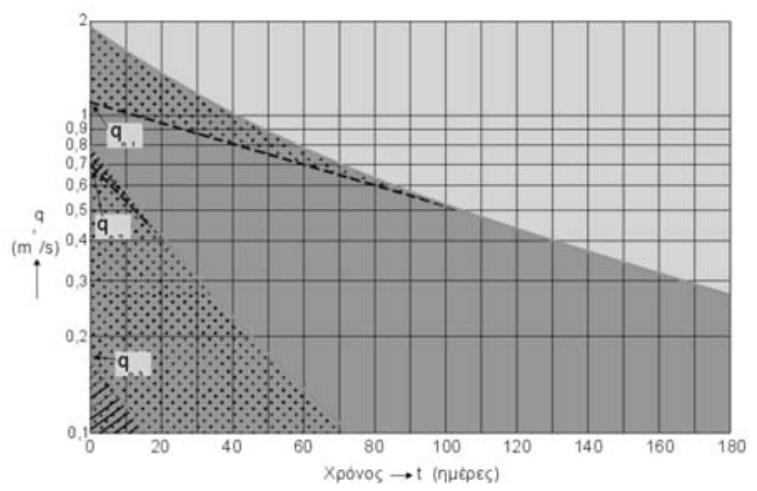

Fig. 14: Application of the Schoeller method at Voula (Trikala) spring.

It is possible for every type of conduits to find the corresponding reserves $\mathrm{W}_{01}, \mathrm{~W}_{02}, \mathrm{~W}_{03}$.

It is marked that Schoeller's formula is multiparametric, i.e. it consists of many parameters $\left(\alpha_{1}, \alpha_{2}\right.$, $\left.\alpha_{3} \ldots\right)$ contrary to the previous formulas that are single-parametric.

This formula is regarded as the basis for the simulation of the springs flow and discharge, especially for the karstic springs.

v. Mangin's formula (1974). Mangin considered that the water flows towards the spring from:

- The saturated zone, i.e. the aquifer, which is described by Maillet's formula.

- The unsaturated zone, directly to the spring, without passing through the saturated zone. This type of water reaches the spring certain days " $t_{i}$ " after the rainfall cessation. After the passage of $t_{i}$ number of days, the water reaches the spring from the saturated zone only.

The first segment of the hydrograph deviates from the exponential curve, Fig. 14: the water that flows out of the spring comes from both the saturated and the unsaturated zones, while the other segment of the recession curve corresponds to the discharge of the saturated zone only. For this reason, the semi-logarithmic diagram logq-t, Fig. 14, at the beginning, deviates from the straight line. Man- 
gin's equation is given by the formula:

$$
\mathrm{q}=\mathrm{q}_{0} \mathrm{e}^{-\mathrm{at}}+\mathrm{q}_{0} * \frac{1-\mathrm{nt}}{1+\varepsilon \mathrm{t}}
$$

The first part is the known Maillet's formula, while the second one is the homographic, bi-parametrical formula of Mangin.

$$
\mathrm{q}^{*}=\mathrm{q}_{0} * \frac{1-\mathrm{nt}}{1+\varepsilon \mathrm{t}}
$$

where $\mathrm{n}=\frac{1}{\mathrm{t}_{\mathrm{i}}}$ is a parameter with dimension $\left[\mathrm{T}^{-1}\right]$ per day and is related to the number of days, during which the water reaches the spring from the unsaturated zone.

$\varepsilon=$ heterogeneity coefficient of the unsaturated zone, which characterize the curvature of the recession curve of the hydrograph.

The Mangin's formula corresponds to the upper dotted part of Fig. 14. The application of this formula is shown at Fig. 15 for the Korisos (Kastoria) spring and the results are $n=0.016 \mathrm{~d}^{-1}\left(\mathrm{t}_{\mathrm{i}}=62\right.$ days), $\varepsilon=0.137, \mathrm{q}_{0} *=1.70 \mathrm{~m}^{3} / \mathrm{sec}$.
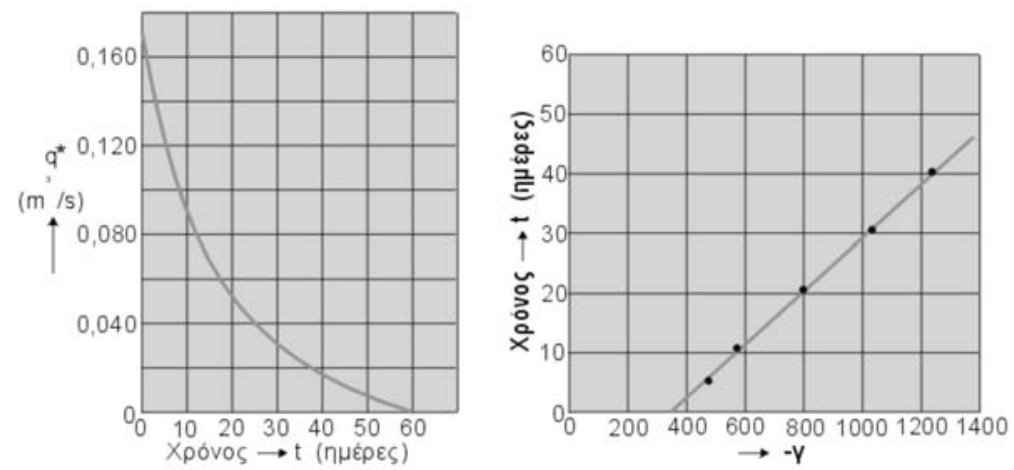

Fig. 15: Application of Mangin's method (1974) at Korisos (Kastoria) spring.

Integration of Mangin's formula (10) provides the reserves of the unsaturated zone.

This formula has significantly contributed to the understanding of the spring mechanism and it is widely used in mathematical simulations.

vi. Finally, it is mentioned that many other formulas have been suggested, mainly tri-parametric, but without significant references in the literature. In addition, many formulas related to the hydrodynamics of the aquifers with specific boundary conditions have been proposed (Berkaloff, 1967, Delhomme, 1971, Tripet, 1969, Galabov, 1972, Burger, 1959 etc.).

\section{Boundary conditions of groundwater systems that feed springs}

i. A simplified aquifer system, as it mentioned, consists of a single spring and can be simulated with a container that is emptied by a tap (a hole), Figure 16 (a). In this case we have a 'simple', 'normal' unit hydrograph. In this hydrograph, the recession curve will have the following feature: while there is no recharge (i.e. dry period without rainfall), the gradient will decrease continuously with the time $t$. In 


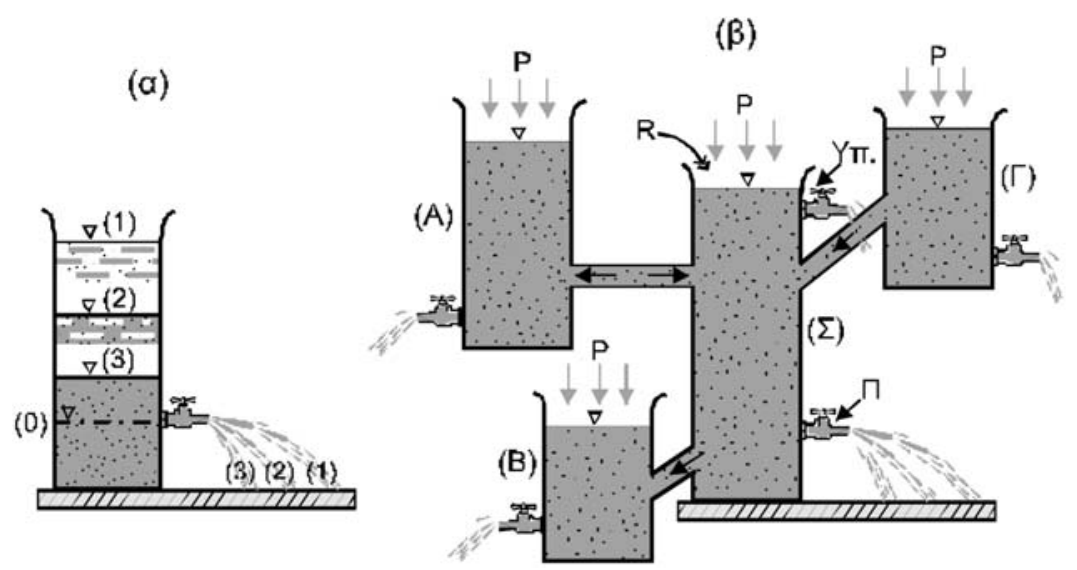

Fig. 16: Spring fed by: $(\alpha)$ «simple», $(\beta)$ «complex» aquifer system.

practice, although, it happens not always or perhaps not so often. The groundwater system that feed the spring is often "complex", Figure 16 (b) and may have various organization, composition and operation.

All this complex organization and operation of the aquifer system that supplies a spring will be reflected and clearly recorded in its hydrograph and especially in the recession curve. There are other ways and methods, however, to determine the complicacy and complexity of an aquifer system that feeds a spring. We will present some of them.

ii. Discharge correlation method. Two springs that belong to the same aquifer system have common features: boundary conditions, piezometric surface, recharge regime, limits of groundwater flow, unsaturated zone. In other words, they have many common factors that influence their discharge. Thus, their discharge should be correlated, so even more strongly as the aforementioned factors are the main factors that determine it.

The application of the discharge correlation method in three different pairs of springs is presented in figure 17:

The first $(\alpha)$, for the neighbouring springs Aposkepou and Kefalariou: Based on 20 measurements, the correlation coefficient of their discharges was estimated to be $r=96,6 \%$. This indicates that both springs belong to the some aquifer system, as was confirmed later with pumping tests.

The second $(\beta)$, for the neighbouring springs «Megali Vrisi» and «Aghios Dimitris» Kserovouniou (northwestern part of mountain of Othris): Based on 21 measurements the correlation coefficient of their discharges was estimated to be $r=88.4 \%$. This coefficient neither so big, nor so small, indicates that both springs belong to an united aquifer system, having nevertheless low hydraulic connection.

The third $(\gamma)$, for the neighbouring springs Korisos and Militsas Kastorias: Based on 25 measurements the correlation coefficient of their discharges was estimated to be $r=81,3 \%$. It is without doubt that both springs are fed from two different aquifer systems, as was confirmed later; the decrease of the discharge of Korisos spring due to pumping, do not significantly influence the discharge of Militsa spring.

Consequently, two neighbouring springs can be:

- completely independent, i.e. being fed from two independent aquifer systems,

- or belong to an aquifer system with a powerless hydraulic connection, 

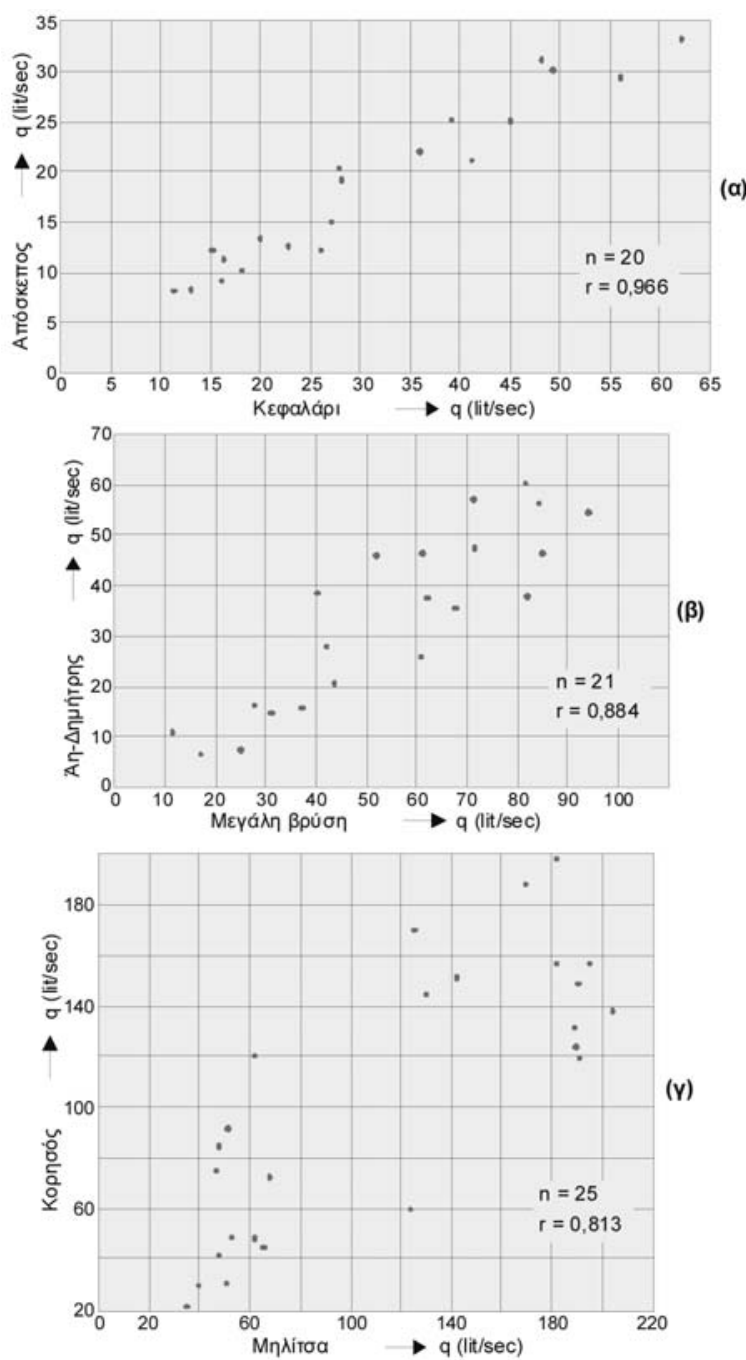

- or, finally, belong to an united aquifer system with a strong hydraulic connection.

Thus, the correlation coefficient $r$ of discharges may take a wide range of values and indicates what happens.

iii. Sorted discharges method. When we have one "simple" aquifer system in which groundwater is discharged by one spring, its discharge follows the law: the number of days with high discharge is relatively small and grows as the discharge diminishes, so the number of days with low discharges in a hydrological year is the largest. Thus, every year is recorded a distribution of discharges, coherent to that of Gauss.

The drawing of a cumulative curve of sorted discharges in a 'simple', 'normal' aquifer system with one spring will be a straight line, while that in a "complex" with "anomalies" and "episodes" will have breaks in the line, up or down in some classes of discharges, which are indicative of the kind of 'anomaly' or 'episode'. 
$(\alpha)$

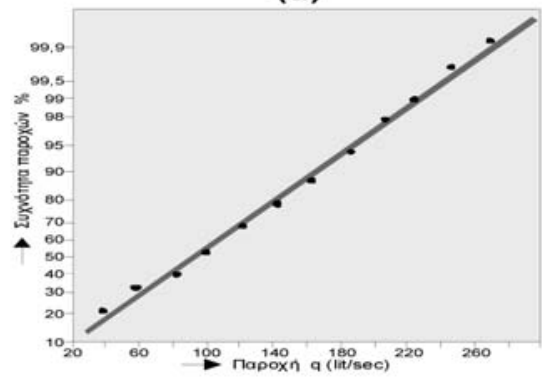

(v)

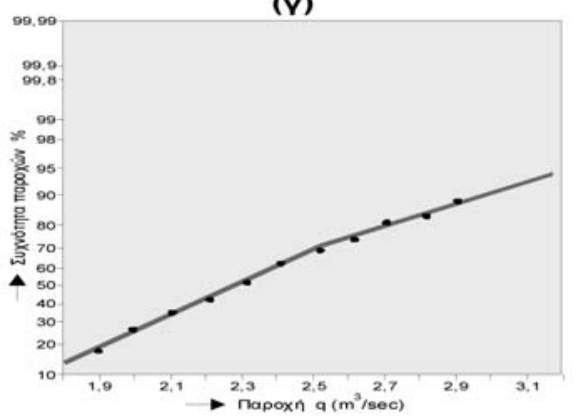

( $\beta$ )

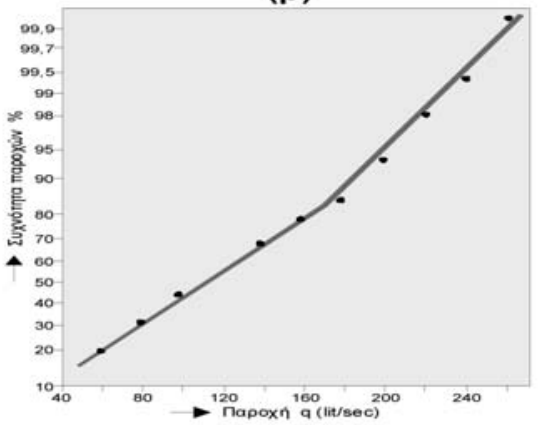

(ठ)

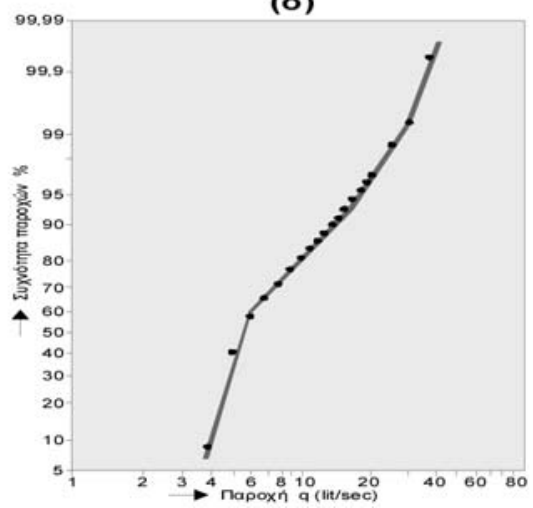

Fig. 18: Cumulative curves of sorting discharges (see the text).

In figure 18, we can see: In fig. 18( $\alpha$ ) the case of a "simple" aquifer system (Korisos spring, Kastoria) with one output, that is one spring, without other "losses".

In fig. 18( $\beta$ ) the case of Militsa spring (Kastoria) that apart from the main spring there is an overflow spring, operating seasonal, when the aquifer system recharges strongly (by rainfall) and the discharge of the main spring is above a critical value. In this point, the curve presents a decline, indicating water loss.

In fig. 18( $\gamma$ ) the case of Almiros spring (Aghios Nikolaos, island of Crete); when the rainfall rate is high, the streams formed in non-karst parts of the recharge zone and flow in its karst parts, supply entire groundwater system. So, when the discharge creates a decline in slope (break) of curve (reverse to that of (b) case) that means recharge.

In fig. 18( $\delta$ ) a complex case with many declines in discharge curve due to "episodes" and organization of aquifer system (Almiros spring, Heraklion, island of Crete) is presented.

iv. Boundary conditions of aquifer system and the recession curve of hydrograph. As mentioned, the shape of the recession curve consists the reflection, "the transfer" of the structure and operation of the entire aquifer system. In this curve depicted quantity data, as well as the whole structure and the boundary conditions of the aquifer system: recharge, losses, "episodes", structure and size of the saturation and the unsaturated zone. The above enter as boundary conditions and form the shape of the recession curve of hydrograph. Any deviation of the general rule that governs the recession curve can be reflected in the hydrograph. In figure 19, six (6) different types of recession curve of spring hydrograph, are presented. Each of which recession curves has special significance: 


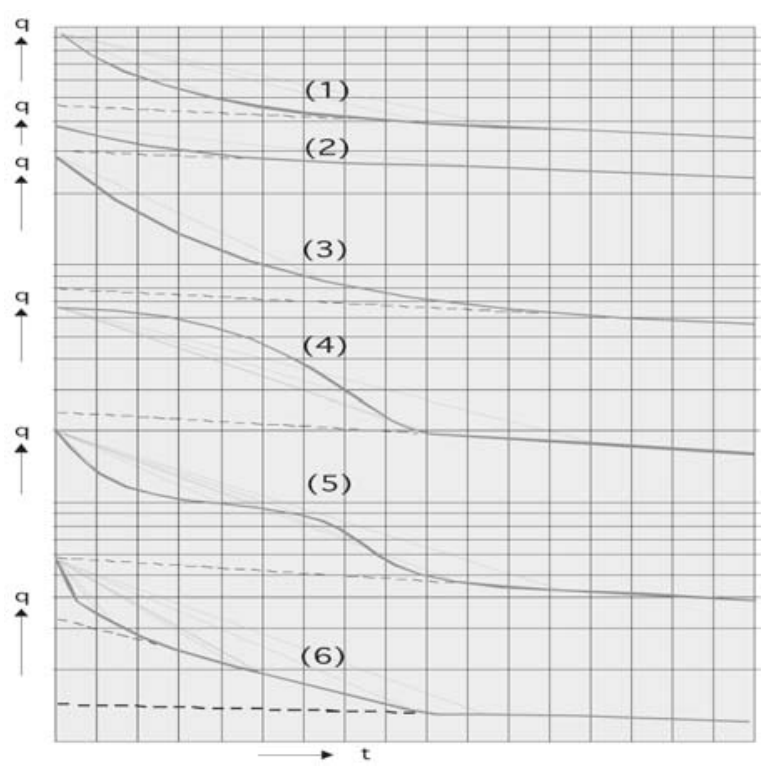

Fig. 19: Different types of recession curves from spring hydrographs (see the text).

The curve (1) from Korisos spring (Kastoria) corresponds to a "simple" and "normal" aquifer system. The saturated zone is "normal" compared to the unsaturated zone.

The curve (2) from Aghios Nikolaos spring (Crete) indicates that the size of the unsaturated zone is small compared to the saturated.

The curve (3) from Stilos-Armeni spring (Crete) indicates that the unsaturated zone is very large compared to the saturated zone.

The curve (4) from Militsa spring (Kastoria) indicates the existence and the seasonal operation of an overflow spring.

The curve (5) from the Mikro Vouno (Chtouri, Thessaly) spring indicates the hydraulic connection between two different semi-independent aquifer systems: one karst system (the principal), and another alluvial system (secondary), which recharge the first one.

The curve (6) from the Maara spring (Aghitis, Drama) means a multiple recharge of the spring: from the main aquifer system, from seasonal lake and from recharge of surface flows.

The first three curves show quantitative differences in the structure of the aquifer system, and the entire range between (1), (2) and (3) is possible and goes back to the relationship between the saturated and the unsaturated zone.

From the other hand, the last three present qualitative differences: different boundary conditions as concerns the recharge, the discharge of the system and the structure-composition and inter-connection of individual components.

v. Cumulative curves of annual precipitation and reduced discharge. When a decrease in discharge of a spring is recorded, it is not obvious from a priori whether is due to any decrease in precipitation or any human intervention, or both. Indeed is possible that human interference with pumping does not happen in the immediate aquifer system that feeds the spring, but in another one that may be located some distance away and has an indirect hydraulic connection with it. 


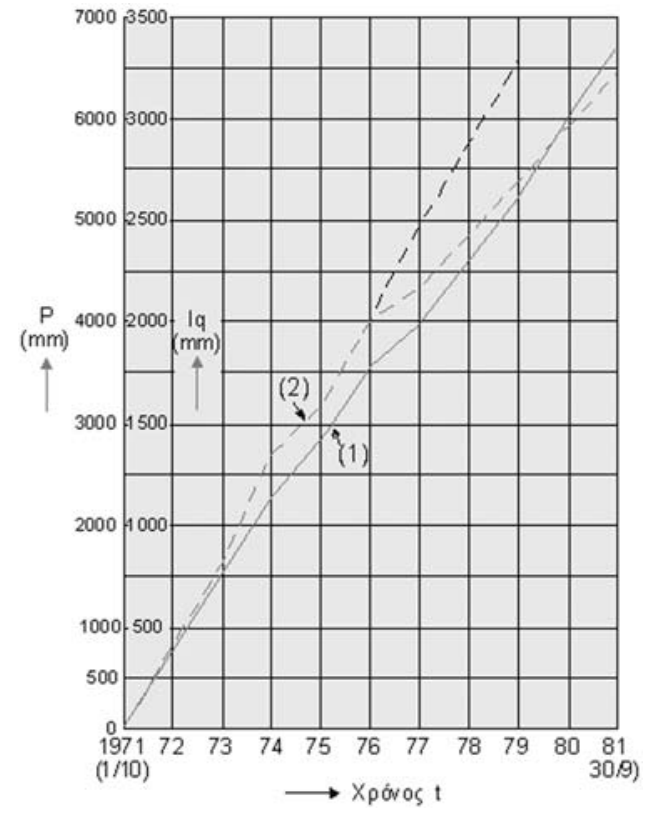

Fig. 20: Cumulative curves of annual precipitation (1) and reduced discharge (2).

The answer can be given with the development of cumulative precipitation curves $\mathrm{P}$ and the reduced discharge Iq (Figure 20). Reduced discharge Iq is the quotient of the annual volume of discharge of a spring by the surface area (zone) of recharge. It is estimated as water height $(\mathrm{mm})$ and corresponds to the amount of infiltrated water. The reduced discharge is practically the height $(\mathrm{mm})$ of the water discharge.

If the reduced discharge Iq changes mean slope compared to the slope of precipitation, is observed human intervention. In figure 20, an example from the Voula spring (Trikala) is presented. By 1975, there were no boreholes drilled in the region. Since 1975 began to be drilled and pumped boreholes in the broader alluvial aquifer in contact with the karstic system that feeds the spring. This caused a gradual deviation of Iq in relation to the average initial course.

\section{Spring capture}

i. One right spring capture to be done the mechanism of discharge must be known, the hydrograph (fluctuation of discharge through time) and the geometry of geological formation. For that reason:

- The exact point of discharge must be known which sometimes does not converge with the point of emerge in the surface, Fig. 21.

- Soil and subsoil must be removed till the point of discharge.

- It must be checked and confirmed if we have a full discharge, or a spout or multiple points of discharge.

- The hydrograph of the spring must be known and the fluctuation of its discharge.

According to these assumptions the planning of the spring capture will be planned. In addition to these we must decide if it is right to be done; but while it decided whether it will be:

- A project of simple spring capture for the total or for a part of its discharge.

- A project of capture and deployment of that spring meaning a project that will aim to the increase of the discharge without modification of the water supplies.

- A project of capture with readjustment of the water supplies. 


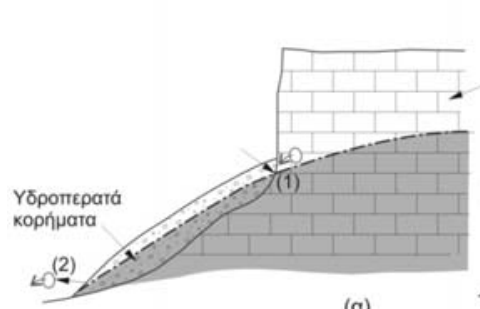

(a)

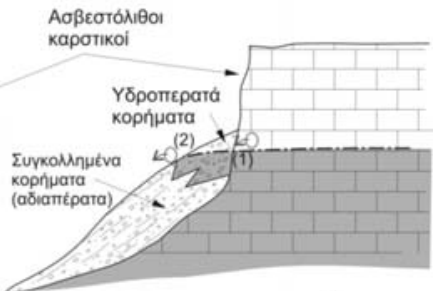

( $\beta)$

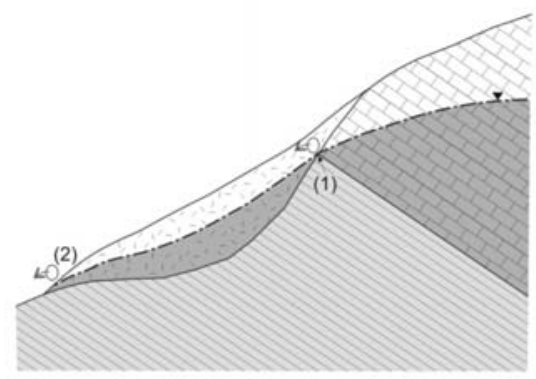

(

Fig. 21: Some cases with different point of subterrain (1) and terrain (2) point of discharge. (a) and (b) from Kallergis (1999) after Letourneur and Michael, (1979) and (c) from Dimopoulos (1983) redrawn - modified completed from the author.

(a)

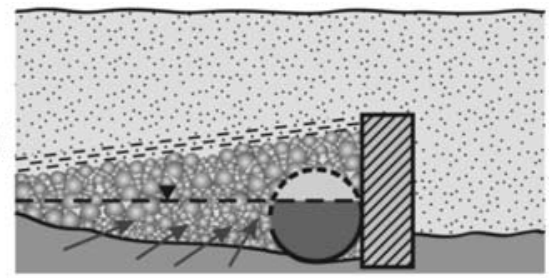

( $\beta)$

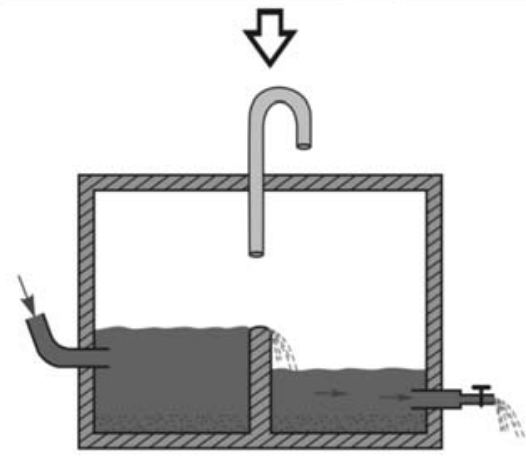

Fig. 22: (a) simple spring capture with perforated pipe vertical to the water direction and waterproofed diaphragm, (b) water capture tank which divert the water in distribution system (see text).

According to the hydrogeological conditions and the pursuing purpose it is possible to develop a water capture of a spring with different projects.

A simple water capture project is shown in Figure 22. This contains a dry wall at the point of discharge (excavation and cleaning already took place), a perforated concrete pipe at the point of spout which is covered with impenetrable clay material or with concrete to its other side. 


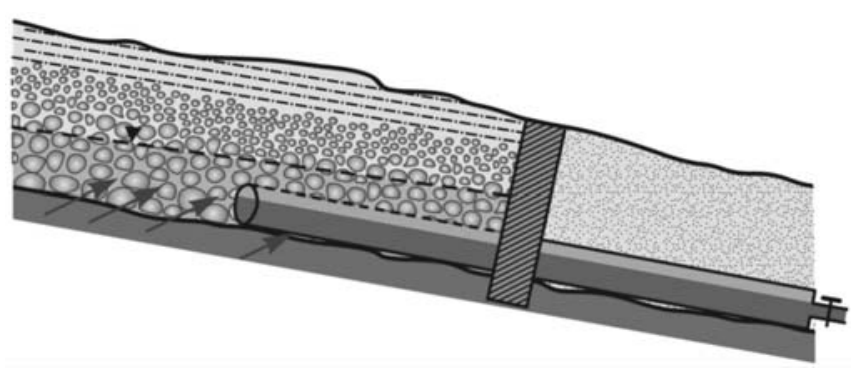

(a)

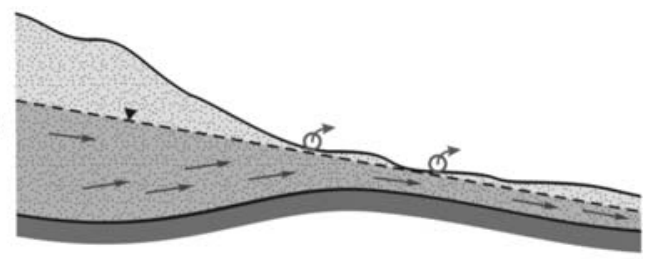

( $\beta)$

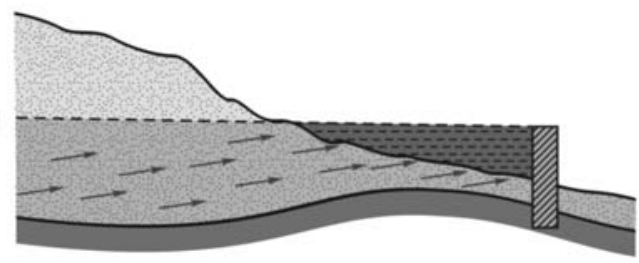

Fig. 23: Spring capture with perforated pipe parallel to the direction of the flow and vertical insulating diaphragm (see text).

Fig. 24: Capture of spring and shallow aquifer with the construction of vertical sealed underground and above the ground diaphragm.

Another way of simple spring capture is shown in Figure 23.Also there, after the excavation and the cleaning of the soil a pipe is placed (concrete, or PVC or stainless material), also perforated in its half or more covered with rock curb, till the exact length of the allocation, this length is usually up to 2-3 m from this point and then the pipe is not perforated. A while after the point from where the pipe is not perforated an impenetrable diaphragm is placed, pushed in the well to the subsoil which is made by concrete or a clay material.

If it is chosen for the capture to be done with a pipe vertical to the direction of the flow (Fig. 22) or parallel to the direction (Fig. 23) or even at the side, depends from the geometry and the extension of the discharge area.

Another way of spring capture with which its deployment is achievable is with the creation of underground or above the ground diaphragm which will restrain the flow (Fig. 24) and is applicable mainly at contact spring in perched or shallow aquifer and rarely in overflow springs as shown in figure.

In figure 25 there is a spring capture with collective tunnel and discharge control tank. Simultaneously it is made partial or total spring regulation of resources, because the water level of the aquifer from point (1) is moving to point (2) and according to the operations from the control tank it can remain permanently there or rise to a middle level or during the year can achieve its initial level (1).

In figure 26 we have a spring capture with the construction of a well (a) and non collective tunnel (b) from its basement.

Finally figure 27 shows a simple spring capture. After the excavation, the cleaning and also the disclosure of the main water carrying crack in a relative cohesive cracking rock, concrete walls (or from other material) are created with piezometric chamber and chamber with filter and conduit leading in the tank or consumption. 


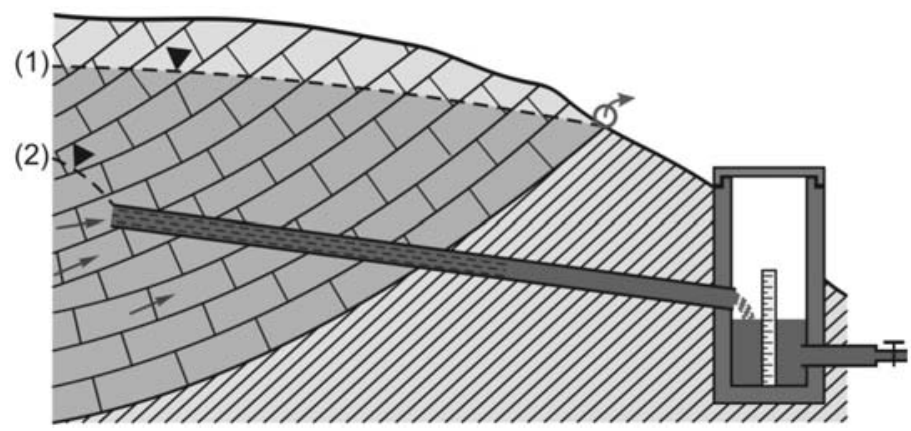

Fig. 25: Spring and aquifer capture with collector trench (1) initial water level, 92) water level during the system operation (Schneider, 1973) redrawn and modified from the author.

(a)

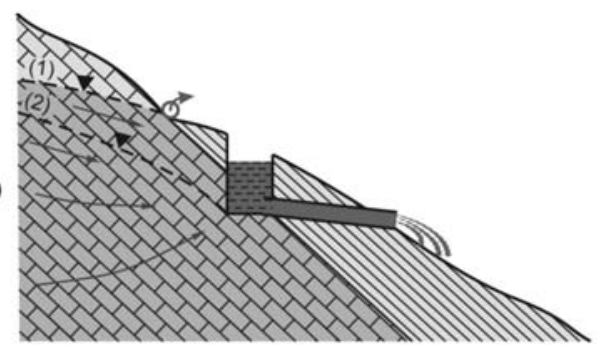

(及)

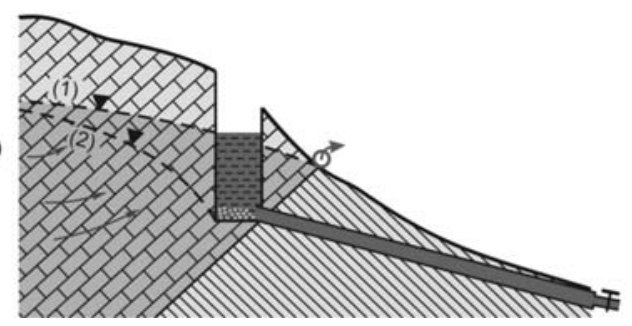

Fig. 26: Spring capture with a well and tunnel aquifer (a) parallel with the impermeable (b) vertical with the impermeable (1) initial water level, (2) water level during the system operation (Schneider, 1973) redrawn, modified and completed by the author.

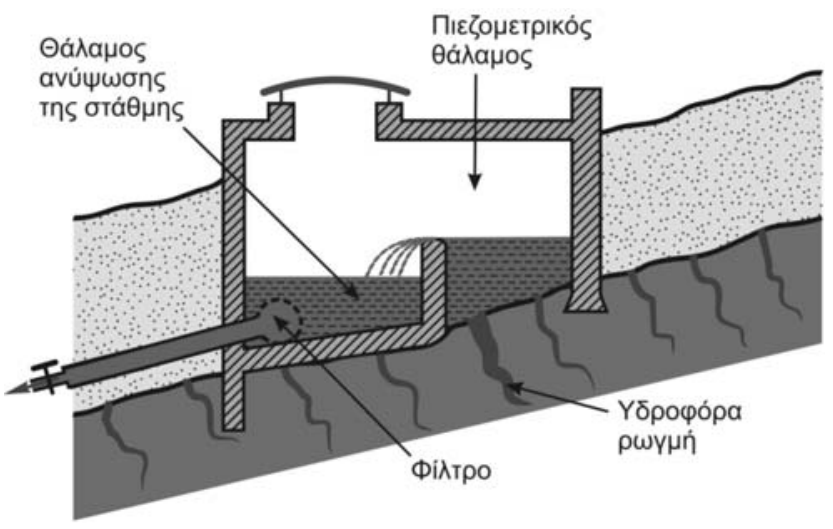

Fig. 27: Spring capture (Kallergis, 1999 after Letourneur and Michel, 1971, redrawn-modified by the author).

Another last case of water capture is shown in figure 28. In this case we have multiple spouts towards a line. Water capture is made with the construction of a water capture trench and tunnel. 


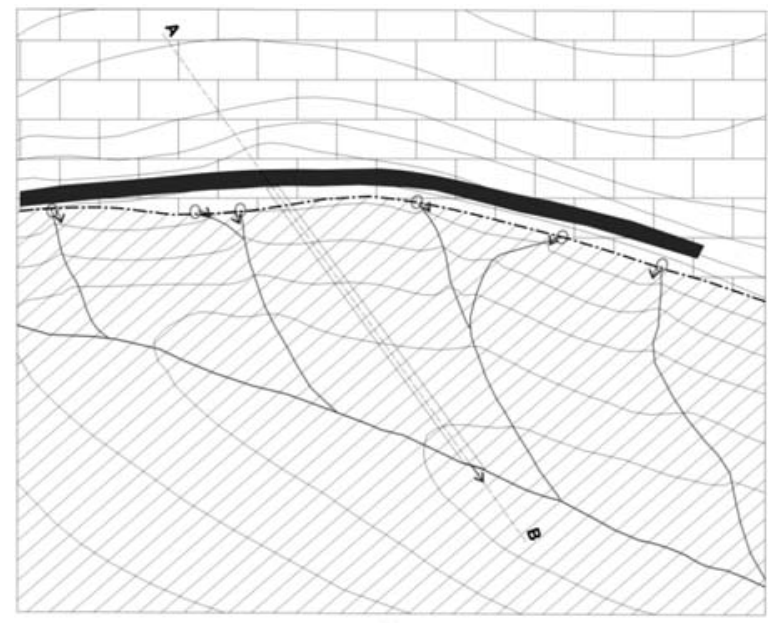

(a)

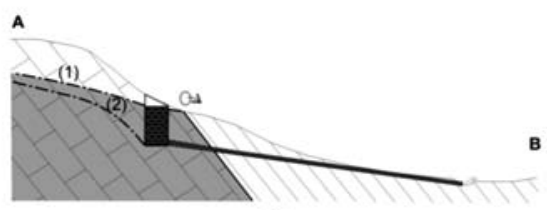

( $\beta)$

Fig. 28: Aquifer capture with collector trench and collector tunnel (Schneider, 1973) redrawn and modified from the author.

\section{References}

Algrot, M., 1967. L' ecoulement de la fontaine de Vaucluse. Travaux du Lab. d' Hydrogeologie-Geochimie, Universite de Bordeaux, $t . X V, 97$ p.

Beauregard, J., 1978. Le bas debits des cours d'eau en France. Etiages normaux et exeptionnels. Frequence et repartition. Hydrog. et Geol. de l' Ing., deuxiere serie, $n^{o} 3$, p. 215-223, editions B.R.G.M., Orleans (France).

Bennett, T. W., 1970. On the design and construction of infiltration galleries. Ground Water, v.8, $n^{\circ} 3$, p. 16-24.

Berkaloff, E., 1967. La limite de validite des formulles courantes de tarrissent du debit. Chronique d' Hydrogeologie, $n^{\circ}$ 10, p. 31-41, editions B.R.G.M., Orleans, France.

Bezes, C., 1976. Contribution a la modelisation des systemes aquifers karstiques. Memoires du C.E.R.G.H., v. X, fasc. I-II, p. 1-135, Montpellier.

Boegli, A., 1980. Karst Hydrography and physical Speleologie. Springer-Verlag, Berlin, 144 p.

Burger, A., 1959. Hydrogeologie du basin de 1'Areuse. Bul. Soc. Neuchat. Geogr., t. 52, $n^{\circ}$ 11, fasc. 1 , p. 5-304.

Dimopoulos, G., 1995. Recherce suv la gestion des ressources hydriques -5: Les travaux de captge (en grec). Ed. du Depart. de Geologie, Univ. De Thessalonique, p. 111-159.

Drogue, C., 1967. Essai de determination des composantes de l' ecoulement des sources karstiques. Chronique d'Hydrog., $n^{\circ}$ 10, p. 43-47, editions du B.R.G.M., Orleans (France). 
Drogue, C., 1969. Contribution a l' etude quantitative des systemes hydrologiques karstiques d' après l' exemple de quelques karst perimediterranees. These d' etat, Univ. de Montpellier, $482 \mathrm{p}$.

Delhomme, J., 1971. Essai de schematization de l' ecoulement de l' eau dans un massif calcaire (determination analytique de la reponse unitaire). Rapport LHM R/71/1, 7p. Labor. d' Hydrologie mathematique, Ecole de Mines, Paris.

Galabov, M., 1972. Sur l' expression mathematique des hydrogrammes des sources et le prognostic du debit. Bul.B.R.G.M. ser. (2), III, $n^{\circ}$ 2/1972, p.52-57, Orleáns, France.

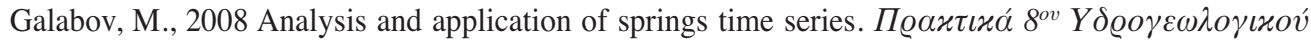

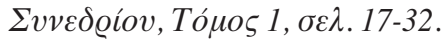

Forkasiewicz, J., Paloc, H. 1967. Le regime de tarissement de la Voux de la Vis. Chronique d' Hydrogeologie, $n^{\circ}$ 10, kp. 59-73, editions B.R.G.M., Orleans, France.

Kallergis, G., 1999. Hydrogéologie Appliquée-Environmentale (en grec) Vol. A. Ed. de Chambre Technique de Grèce, 331 p.

Letournier, J., Michel, R., 1971. Geologie du genie civil. Ed. Armand Colin, Paris, 436 p.

Maillet, E., 1905. Essais d' hydraulique souterraine et fluviale. Herman, Paris, 218 p+24 fig., 11 graph., h.t.

Mangin, A., 1974. Contribution a l' etude hydrodynamique des aquifers karstiques, premiere partie. Ann. Speleol. 29, $n^{\circ} 3$, p. 283-332.

Mangin,A., 1974. Contribution a l' etude hydrodynamique des aquifers karstiques, deuxieme partie. Ann. Speleol. T. 26, fasc. 2, p. 283-329, Moulis (Ariege), France.

Mijatovic, B., 1974. Determination de la transmissivite et du coefficient d' emmagasinement par la courbe de tarissement dans les aquifers karstiques. Mem. A.I.H., Reunion de Montpellier, $n^{\circ}$ 10, p. 225-230.

Schneider, H., 1973. Die Wassererchliessung. Ed. Nulkan - Verlag, 847 p.

Schoeller, H., 1967. Hydrodynamique dans le karst (ecoulement et emmagasinement). Chronique d' Hydrogeologie $n^{\circ}$ 10, p. 7-21, edition B.R.G.M., Orleans, France.

Soulios, G., 1985. Recherches sur l' unite des systemes aquifers karstiques d' après des exemples du karst hellenique. Journal of Hydrology, v. 81, p. 333-354.

SoulioS, G., 1991. Contribution a l' etude des courbes de recession des sources karstiques: exemples du pays helleniques. Journal of Hydrology, v. 124, p. 29-42.

Soulios, G., 2008. Hydrogéologie générale. Deuxième volume (en grec). Ed. Univ. Studio Press, 349 p.

Tison, G., 1960. Courbe de tarrissement, coefficient d' ecoulement et permeabilite du bassin. Memoires A.I.H.S., p. 229-243.

Todd, K.D., 1980. Groundwater Hydrology. John Wiley \& Sons, New York, $2^{\text {nd }}$ ed., 535 p.

Tripet, J., 1969. Une methode d' approache de l' analyse du tarrissement d' une source karstique. Etude preliminaire. Mem. B.R.G.M., $n^{\circ}$ 76, p. 701-709, Orleans, France.

Welchert, W. T., Freeman, B. N., 1973. Horizontal wells. Jour. Range Management, v. 26, p. 253-256. 